Archaeological Journal

\title{
English Municipal Heraldry
}

\section{W. H. St. John Hope M.A.}

To cite this article: W. H. St. John Hope M.A. (1895) English Municipal Heraldry, Archaeological Journal, 52:1, 173-197, DOI: 10.1080/00665983.1895.10852667

To link to this article: http://dx.doi.org/10.1080/00665983.1895.10852667

曲 Published online: 16 Jul 2014.

Submit your article to this journal 중

III Article views: 2

Q View related articles $₫$ 


\section{ENGLISH MUNICIPAL HERALDRY. ${ }^{1}$}

By W. H. Sт. JOHX HOPE, M.A.

I have lately had occasion, for reasons with which I need not trouble you, to enquire what has been written on the history and origin of municipal heraldry, but with the exception of such catalogues as those of Guillim, Edmondson, and Berry, and a recent pretentious work called The Book of Public Arms, I am unable to find anything on the subject, for none of these writers attempts to explain either the origin or the meaning of the numerous arms borne by the incorporated cities and boroughs of England and Wales.

This small amount of attention that has been bestowed upon municipal heraldry may perhaps be accounted for by the nature of the authorities to which we must turn for evidence.

In the case of personal heraldry we have rolls of arms and such like documents, and numerous monuments, from very early times, as well as an abundance of well-known seals, and at a later date formal grants from the Heralds' College.

But the only authorities for municipal heraldry before the reign of Elizabeth, and also to a large extent after, are the common and official seals used by the corporations. These, from the nature of the documents, leases and the like, to which they are attached, are of very local and limited distribution, and it is no wonder that municipal seals and the armorial evidence which they furnish should be so little known.

Independently of their local distribution the study of municipal seals, and indeed of any other class, is beset with difficulties, inasmuch as there are so few fairly complete collections of impressions or casts in existence, available for that close and comparative examination which is absolutely necessary to a knowledge of them

The most accessible of these collections, though perhaps

1 Read at the Monthly Meeting of the Institute, November 7 th, 1894. 
the least known, is that made by the late Mr. Albert Way, and by him bequeathed to the Society of Antiquaries. There has also come into my own hands during the last few years a large number of impressions of existing municipal seals, which, when added to those belonging to the Society of Antiquaries, will with them form the most complete series hitherto got together.

It is mainly upon the evidence furnished by these two collections that I have based the subject of my paper.

The assumption of arms by corporate bodies, though hardly consonant with the best and truest principles of ancient armory, began at a much earlier date than is commonly supposed.

In the oldest municipal seals which display shields, these bear simply the royal arms of England, in reference to the king as over-lord; but before the end of the thirteenth century there is evidence that the towns were beginning to adopt arms of their own.

The earliest of these arms to which a definite date can be attached seems to be those of the city of Chester. They occur on the lesser Statute Merchant seal of 1283, and represent the three lions of England combined, by

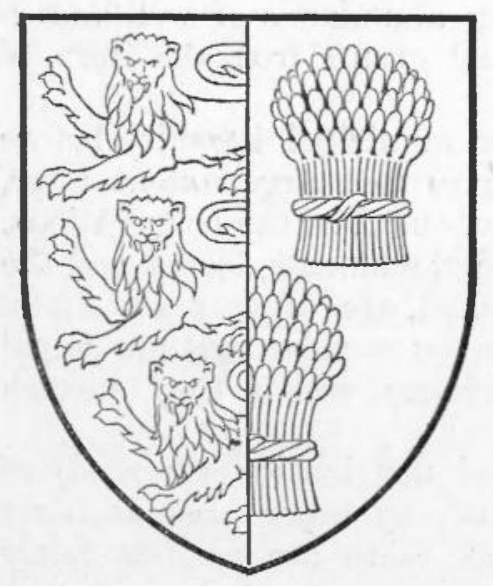

AXCIRNT ARMS OF THE CITY OF CHESTER.

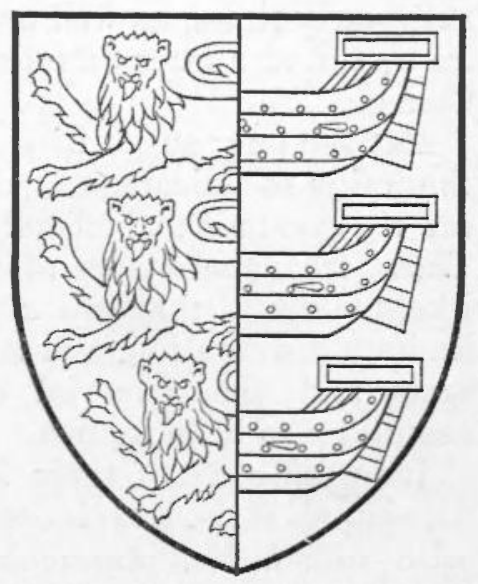

ARMS OF THB CINQUE PORTS.

the curious and ugly process called dimidiation, with the three golden garbs on a blue field of the earldom of Chester. 
Of about the same time, or very little later, since they occur on the dated Dover seal of 1305 , are the singular arms borne by the several corporations of the Cinque Ports and their dependencies, ${ }^{1}$ which are compounded of the three lions of England dimidiated with the hulls of three ships.

These curious monsters, half lion, half ship, may be compared with those in the, probably, contemporary arms of Great Yarmouth, which are formed of the lions of England as before, dimidiated with three herrings. The present arms of Stamford, England impaling De Warenne, very likely originated in a dimidiated shield.

The fine late thirteenth century seal of Kingston-onThames has a shield bearing three fish and a letter $R$, perhaps in allusion to its ancient fisheries, which are specially mentioned in Domesday Book. The first Droitwich seal, of about the same date, displays a shield charged with two lions passant surmounting or pierced by a sword. These are probably derived from the personal arms of a lord of the manor of Wich, but I have not ret been able to

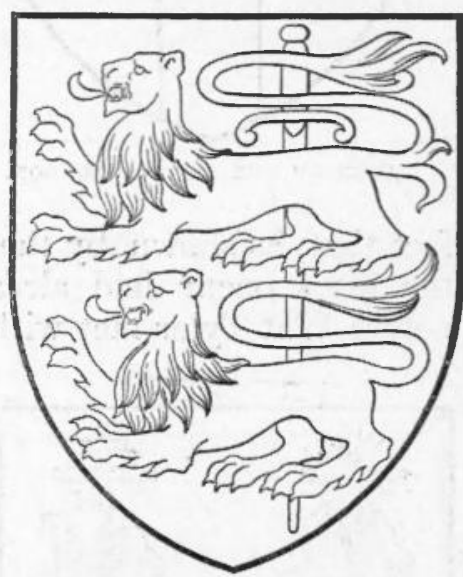

FIRST ARYS OF THE TOWY OF DROITWICH. definitely assign them. The sword, however, refers to William Longespee, Earl of Salisbury, who was lord of Wich in the reigns of John and Henry III., until his death in 1226 .

During the fourteenth century several interesting arms made their appearance.

Foremost among these is the beautiful shield of the city of London, which combines the sword of St. Paul with the cross of St. George. It occurs first on the second mayoralty seal of 1381 , but is probably at least fifty years older. The popular notion that the sword

Dorer, Sandwich, Romney, Hythe, Winchelsea, and Rye; also Hastings, Deal, Farersham, Lydd, Tenterden, and Ipswich. 
really represents the dagger wherewith Sir William Walworth slew Wat Tyler is effectually disposed of by the

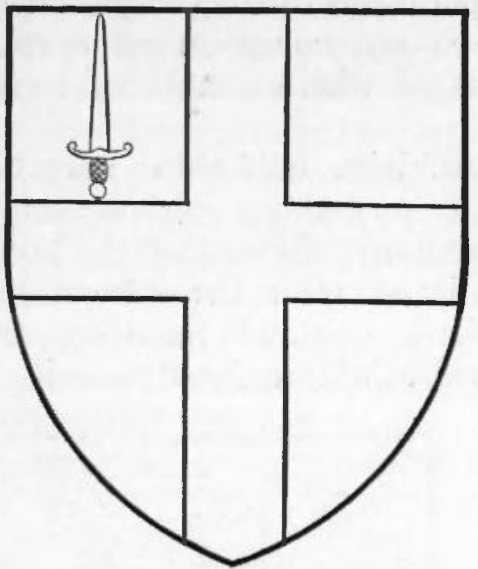

ARMS OF THE CITY OF LONDON.

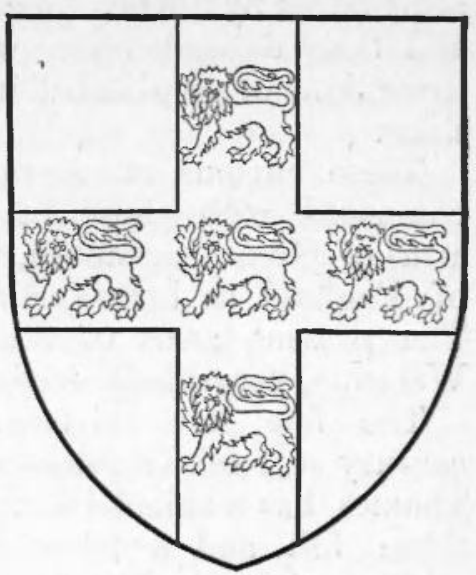

ARMS OF THE CITY OF YORK.

fact that, as shown by the city records, the seal on which the arms occur had already been in use three months before Wat Tyler met with his end.

Another late fourteenth

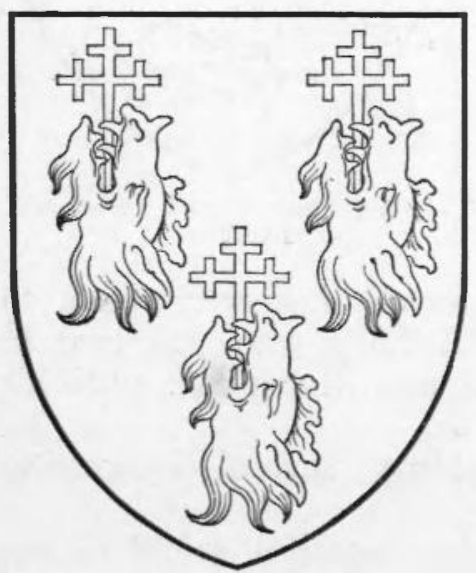

ARMS OF THE BOROTGH OF LTIN. century seal, that of the mayoralty of York, exhibits the charming arms of that city, argent, a cross of $S$. George charged with five lions of England. On seals of about the same date appear the arms of Lynn, azure, three dragons' headserased anderect, each pierced with a cross or. These are now frequently but most ignorantly drawn and blazoned as conger-eels' heads, but they of course refer to St. Margaret, the patron saint of Lynn, who is usually represented trampling on or bursting forth from a dragon and piercing him with a cross staff.

The seal of Lewes also shows the arms of that town, composed of the blue and gold checkers of the De 
Warennes, who were for so long the lords of Lewes, with a sinister quarter charged with a lion rampant on a crusilly field. This perhaps refers to the powerful Sussex family of De Braose, but I have not yet been able to establish their connection with the town of Lewes. In any case we have here an interesting example of the combination of two personal shields of arms to form a new one for the town.

At the beginning of the fifteenth century, on the seals used by the chancellors of the University, we meet with the canting arms now borne by the city of Oxford, argent, an ox gules, crossing a ford proper. On the early city seals this device occurs as a badge or rebus only, and it is a question whether it was not at first used as the arms of the University.

The Shrewsbury arms. azure, three lions' heads (or faces) or, are shown on the fine dated seal of 1425. They probably refer to the royal arms, despite the blue field on which they are now borne. The curious quarterly shield of Shaftesbury, first and fourth a fleur-de-lis, second and third a leopard's head; over all a cross, occurs on a charming little seal of which impressions exist as early as 1428. These arms are now blazoned with the field and the cross quarterly argent

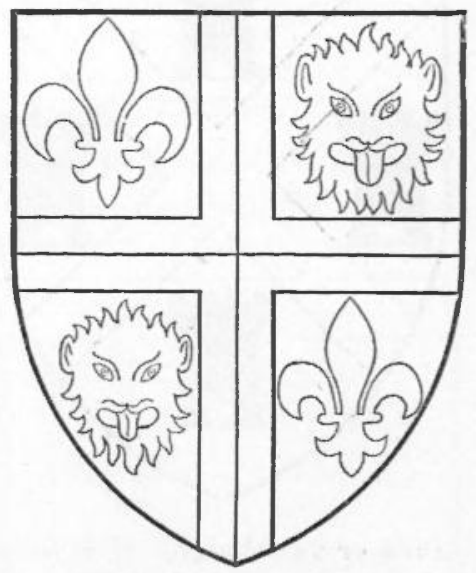

ARMS OF THE BOROUGH OF SHAPTESBURY.

and azure, and the charges counterchanged. But the quarters should, I think, more probably be azure and gules and the charges or. They would thus, instead of being meaningless, have an interesting reference to the royal arms. The cross must have been gold or silver and perhaps refers to the great Benedictine abbey of Shaftesbury, the abbess of which divided the manor with the king.

The second Droitwich seal, of early fifteenth century date, may here be noticed for the singular arms it bears. 
These are composed of the lions and long sword already noticed as on the first seal, impaled with quarterly, 1 and 4, checky argent and sable, 2 and 3, gules, two peels or salt baskets or. After much consideration I am inclined to think that this curious addition to the old arms alludes to the payments or dues to the king for the brine works, exemplified by the checker board on which the accounts were made up, and the baskets to the salt industry from which the town derives its old name. Possibly the first half of the place-name, "Droit," may have reference to the royal dues, in which case the quarterly impalement may be a canting allusion to the name Droitwich.

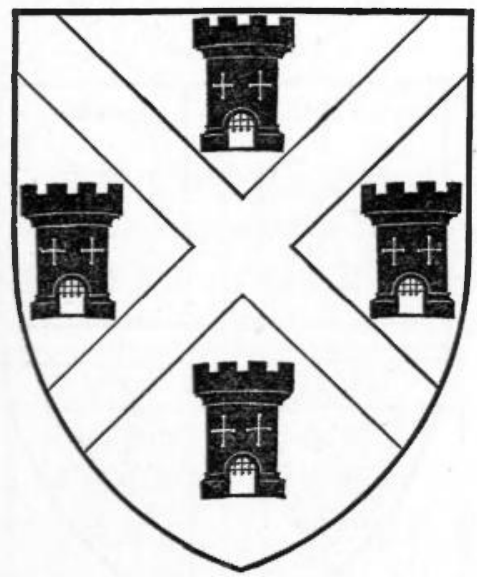

ARMS OF THE BOROCGH OF PLYMOUTH.

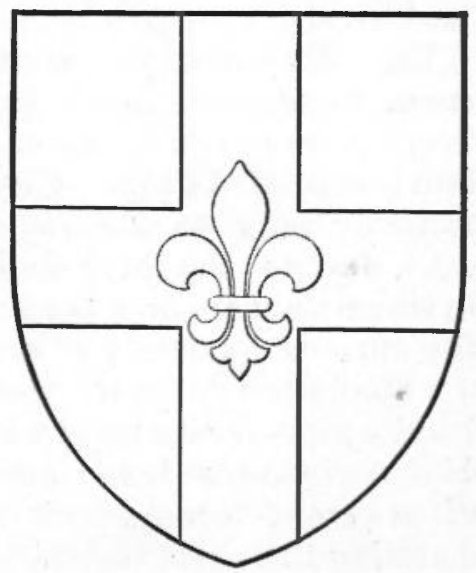

ARMS OF THE CITY OF LINCOLN.

Another early shield of a date not later than 1430 is that of Kingston-on-Hull, azure, three crowns or, in allusion probably to its name of the King's-town. The same charges on a field sable occur later as the arms of Boston.

The fine mayoralty seal of Plymouth, which almost certainly dates from the incorporation charter of 1440 , introduces a very pretty shield of arms : argent, a saltire vert betueen four touers sable. Here the cross is that of St. Andrew, the patron saint of Plymouth, while the towers refer to the fortifications of this, even then, most important stronghold. 
On the reverse of the Tenterden seal, which dates from the charter of 1447 , is a shield in base, where the arms of the corporations are usually placed, bearing on a bend between four lions' heads erased, three estoiles of eight points. These are the arms of Thomas Petlesdon, who was the first bailiff under the new charter. Despite their obviously personal character, it is curious to find that their position in the place of the corporate arms should have led to their subsequent use as the arms of the town; at any rate they are displayed as such on the sail of the ship which

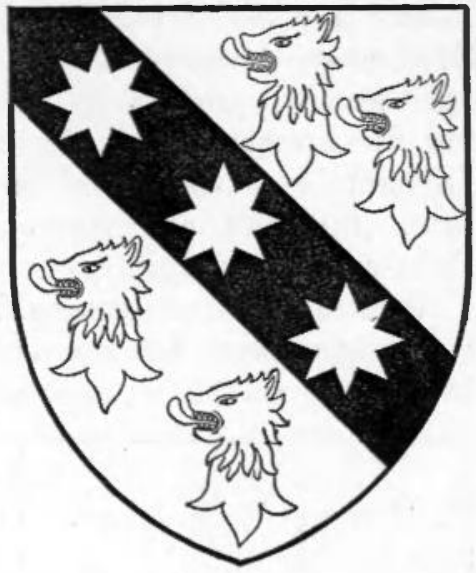

ARYS OF THOMAS PETLESDON, FIRST BAILIFF OF TENDERDEN, $14+7$.

forms the device of the seventeenth century mayoralty seal. On the seal of 1447 the ship has on the sail the arms of the Cinque Ports, of which Tenterden was a dependency.

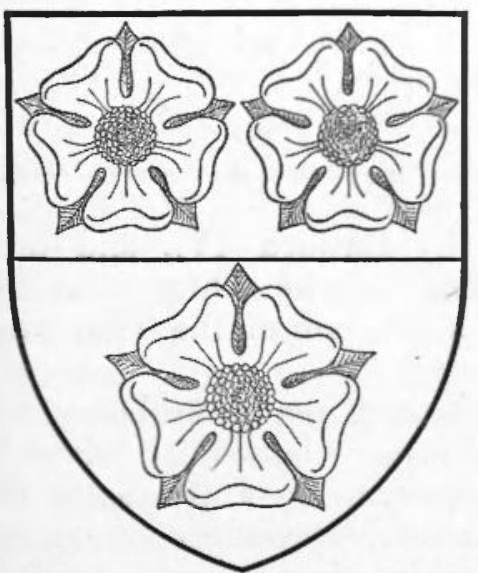

ARMS OP THE TOWN OF SOUTHAMPTON.

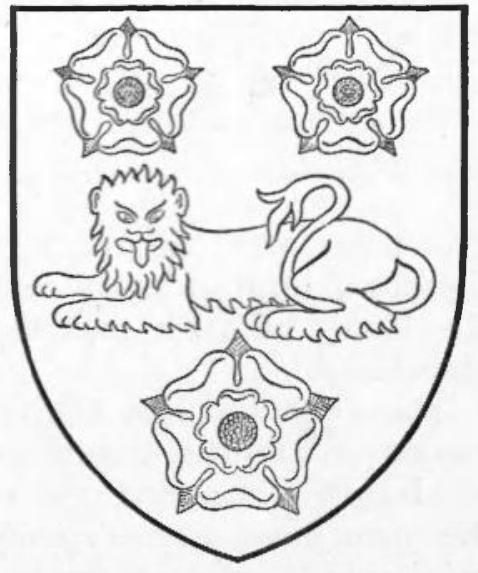

ARMS OF THE BOROUGH OF LUDLOW.

On the common seal made for the city of Lincoln in 1449 we meet with another simple and interesting shield, argent, on a cross of St. George a fleur-de-lis or. These 
arms are probably a century older than the seal. The fleur-de-lis clearly refers to the Blessed Virgin Mary, in whose honour the cathedral church is dedicated.

The arms of Southampton, per fess argent and gules, three roses counterchanged, are stated in the grant of a crest and supporters in 1575 to have been borne since the incorporation of the town by Henry VI. in 1445. The simple character of the shield agrees well with this date, and the red roses of the House of Lancaster plainly tell its origin.

An equally interesting shield is that of Ludlow, azure, a lion couchant between three roses argent. These arms first occur on the common seal of 1461, in which year
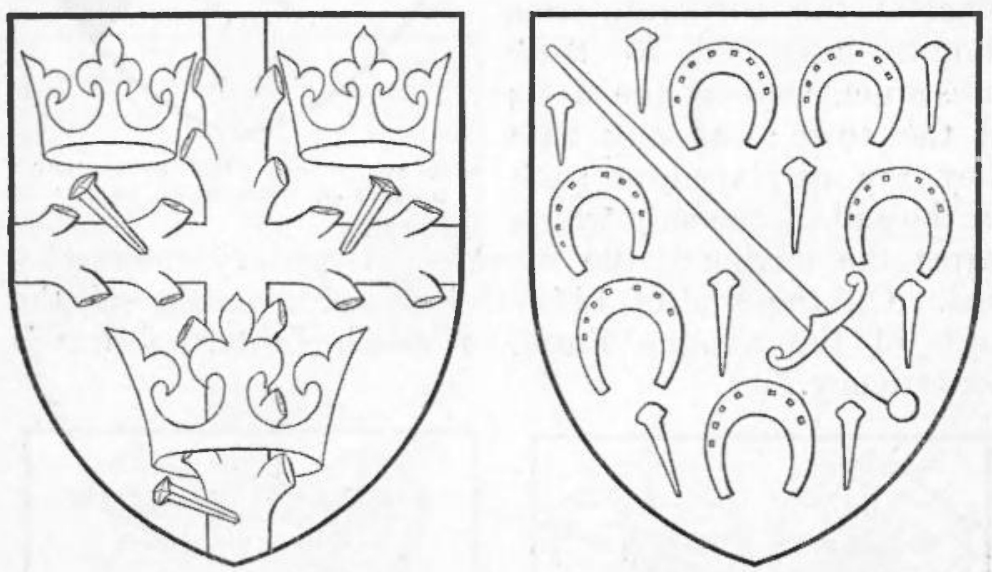

ARMS OF THE BOROUGH OF COLCHESTER. FIRST ARMS OF THE CITY OF GLOUCESTER.

the town was incorporated by Edward IV., and are therefore appropriately composed of the white roses of the House of York and the white lion of the House of March.

The splendid seal of Colchester, made probably to commemorate the granting of a new charter by Edward IV. in 1461, bears on the obverse, in base, the arms of the town, gules, a cross raguly argent, between two crowns in chief and passing through a third in base or. As the principal subject of the seal is a figure of St. Helen, who is asserted to have been born at Colchester, clasping the Cross and tinree nails, the principal charge in the arms is easily explained, especially since on the seal it is shown 
pierced with three nails. The crowns of course refer to the patron saint of East Anglia, St. Edmund the King, whose martyrdom may be indicated by the red field.

The arms themselves are of earlier date than the seal, since they also occur (but without the nails in the cross) in the initial letter of the charter granted to the town by Henry V. This also contains a seated figure of St. Helen, with the Cross held up before her by a kneeling king.

A precisely similar shield, but with the cross vert, is claimed as the arms of Nottingham, and so entered in the Visitation of 1569 . I cannot, however, find any other or earlier authority for them, nor can I see how they are to be interpreted, or what possible connection they can have with Nottingham.

On the mayoralty seal of Gloucester, made in 1483 , is shown an interesting shield which for fifty years was used as the city arms. It bears the newly granted sword of state bendwise between six horseshoes on a field semee of horsenails, in allusion to the staple trade of the town.

Another shield of arms for which there may be early authority is that of the city of Hereford, gules three lions passant gardant in pale argent. These arms occur, in conjunction with the royal arms, on the late fifteenth century state sword, but it is doubtful whether the lions are or or argent, or the arms of England or Hereford. Long usage would point to the latter, but they are clearly derived from the royal arms. So, too, must be the arms of New Romney, which are asserted to be azure, three lions passant gardant or, but I do not know upon what authority. Maldon bears azure, three lions passant regardant or, which are probably but a blundered version of the arms of England. Appleby also claims on the authority of its interesting thirteenth century seal, to bear three crowned lions passant gardant, but the arms on the seal are unquestionably the uncrowned lions of England.

With the possible exception of those of Oxford the whole of the arms that have so far been described are regular heraldic compositions of the same character as personal arms. There are, however, a considerable number of cities and towns whose arms have obviously 
been formed, as in the case of Oxford, by placing upon shields the devices of their common or official seals. Many of these devices when so treated become most appropriate armorial bearings, and it is only natural that they should have suggested themselves for the purpose.

We have evidence, too, that the practice began quite early. The arms of Norwich, for example, gules, a tripletowered castle argent and in base a lion of England appear on the first mayoralty seal of 1404-5. They are, however, clearly derived from the old bailiff"s seal and counterseal, which bore a castle and a lion respectively, These were combined to form the device of the new common seal made when the constitution of the city was changed in

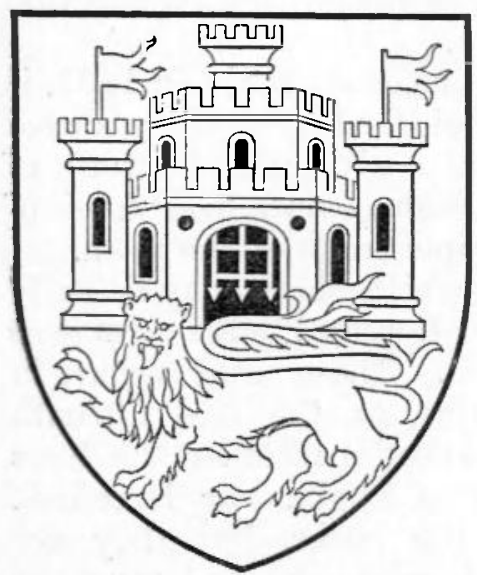

ARMS OF THE CITY OF NORWICH.

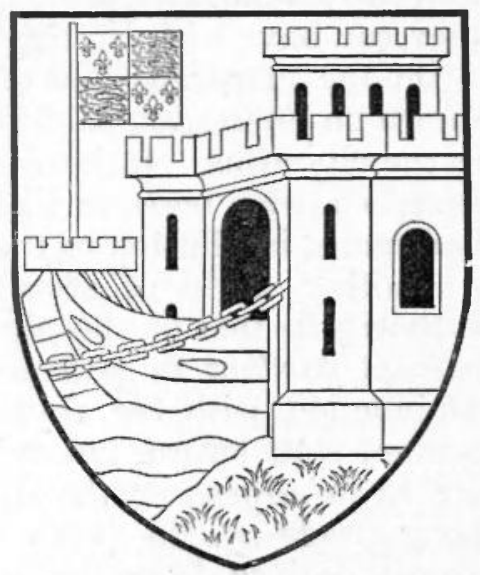

ARMS OF THE CITY OF BRISTOL.

1404-5. The meaning of the charges on the shield is of course obvious. Another early instance of these borrowed devices is furnished by the arms of Bristol, which, as now borne, may be shortly blazoned as: gules, a castle argent, issuing therefrom a ship on the waves proper. These are shown as the city arms on the "pearl sword" which was given shortly after 1431, and also in the curious MS. belonging to the corporation known as Ricart's Kalendar, temp. Edward IV. The arms are derived from the fourteenth century mayoralty seals, which bear representations of a castellated water-gate, with the prow of a vessel issuing from it. 
The arms of Lancaster, per fess, azure a fleur-de-lis or, and gules a lion of England, have probably been taken from a similar seal to that of Walden (now Saffron Walden) which bears a lion of England with a fleur-delis above. An old mayoralty seal of Chichester has a variant of this, but borne on a shield, a lion passant regardant, with a fleur-de-lis in base. In at any rate the first two cases, the allusion to the royal arms is obvious.

To the end of the fifteenth century possibly belong three shields of arms formed by placing the devices or badges of the seals on parti-coloured fields of the livery colours :

Exeter: Per pale gules and sable, a triangular triple-towered castle or. (Visitation of 1564.)

Coventry : Per pale gules and vert, an elephant and castle or. (Visitation of 1619.)

Buckingham : Per pale yules and sable, a swan with wings expanded argent, gorged with a coronet and chained or. (Visitation of 1566.)

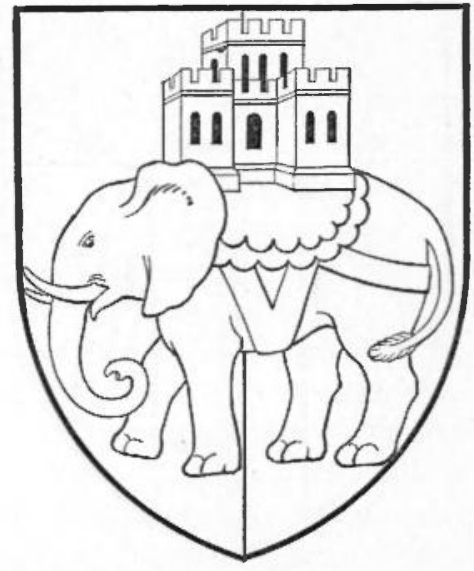

ARMS OF THE CITY OF COVENTRY.

As there appear to be no

other instances of arms derived from seals which can be shown to be of earlier date than the sixteenth century, it will be more convenient to defer the consideration of them while we examine such arms as were formally granted between the foundation of the Heralds' College in 1483-4, and the abolition of the monarchy in 1649 , when the functions of the College were practically suspended until the Restoration.

The decadence of the true principles of armory which set in after the Wars of the Roses is well illustrated by the arms of some of the later corporations, and in particular by those that have been granted by the College of Arms. 
In place of the simple bearings of the fourteenth and fifteenth centuries, such as I have described, all kinds of elaborate combinations may now be met with, and in more than one case the heralds seem to have gone out of their way to supersede an interesting and intelligible shield of arms, which had not their "authority," by another that can only be called ridiculous.

The city of Gloucester, for instance, as I have shown, received or assumed (as it was certainly at liberty to do) most appropriate arms in 1483. These were set aside in 1538 by Christopher Barker, Garter, who granted in their stead this extraordinary concoction: Vert, on a pale or,

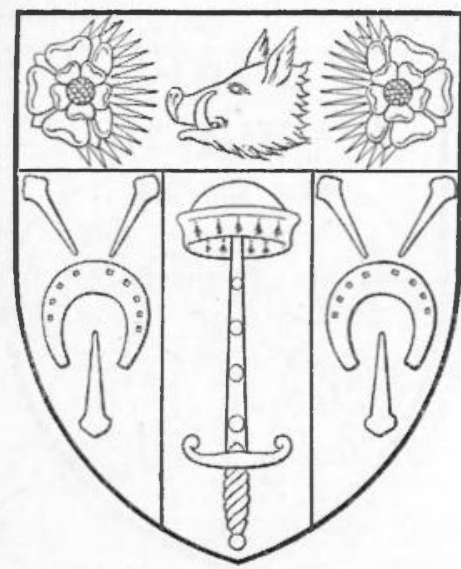

SBCOND ARMS OF THE CITY OF GLOJCESTER.

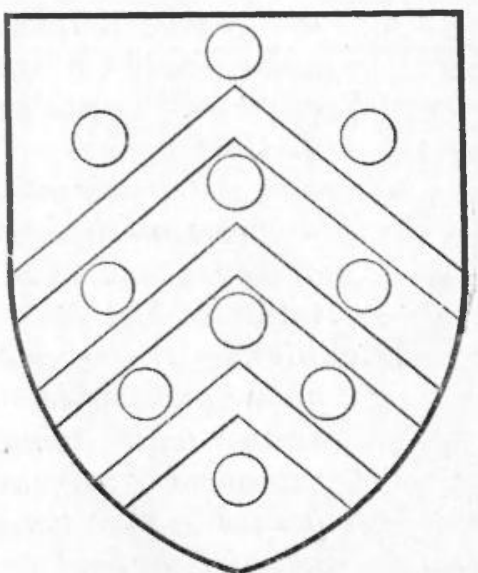

THIRD ARIS OF THE CITY OF GLOUCESTER.

a sword azure, bezanted, hilt and pommel gules, on the point a cap of maintenance purpure, lined ermine, all between two horseshoes, each between three horsenails in triangle argent; on a chief per pale or and purpure a boar's head couped silver, between two demi-roses-en-soleil, the dexter gules, the sinister argent, both barbed vert and rayed or. The city endured these arms for more than a century, but was relieved of them in 1652 by another Garter, Edward Bishe, who for reasons of his own substituted the arms that have since been used: or, three chevronels gules, between ten torteaux $, 3,3,3,1$. These are clearly a combination of the arms of De Clare, the ancient lords of Gloucester, with 
those of the see of Worcester, to which Gloucester was formerly attached ${ }^{1}$.

Again, the borough of Ipswich had for a long time used the curious dimidiated arms of the Cinque Ports, of which it was a dependency. But in granting a crest and supporters to the town in 1561, these arms were set aside by William Hervy, then Clarencieux, and converted into gules, a lion rampant gardant or, impaling azure three demi-ships or. The demi-ships are drawn in the grant as they had been before, as part of a dimidiated shield. Hervy states that he had searched in the registers and records of his office for the right and ancient arms of the town, and having found the antiquity of them, and being unable to alter or change them without the prejudice of the townsfolk, he accordingly " ratifies and confirms them." It does not say much for the worthy herald's researches that he was able to find arms that had no previous existence, unless perchance in his own imagination.

A more reasonable case of interference occurred in 1645, when a special augmentation was added to the ancient arms of Hereford by Sir Edward Walker, Garter, at the command and direction of Charles I., to commemorate the successful resistance of the citizens for five weeks against the besieging Scottish army. The augmentation appropriately took the form of a blue bordure charged with ten silver saltires, or "Scottish crosses" as they are called in the grant, which also included suitable supporters and crest.

Among other more or less elaborate shields granted by the Heralds' College during the sixteenth and early part of the seventeenth century may be mentioned those of :

Morpeth (1552): Barry of ten argent and gules, a triple-towered castle or, all within a bordure azure charged with ten martlets gold;

Newark (1561): Barry wavy of six argent and azure, on a chief gules a peacock in his pride between a fleur-de-lis and a lion passant gardant or; 
Launceston (1573): Gules, a three-storied castle or, within a bordure azure charged with eight turrets gold;

Cambridge (1575): Gules, a bridge or ; in chief a fleur-de-lis of the last between two roses argent; in base three boats sable on the waves proper;

Eye (1592): Azure, a cross flory between four martlets or, in chief on a rose branch proper issuing from the cross and bearing six roses argent, an eagle volant silver, crowned gold;

Westminster (1601): Azure, a portcullis or ; on a chief of the last between two roses gules a pale of the field charged with a cross patonce between five martlets gold;

Evesham (1604): Azure, a prince's coronet, between two ostrich feathers argent, the quills chained or, in chief, and a gold garb in base, all within a bordure sable bezantee;

Bury St. Edmunds (1606): Azure, three crowns or, each transfixed with two arrows saltirewise argent;

Hadleigh (1615): Azure, a chevron erminois between three woolsacks argent; and

Gravesend (1636): Ar-

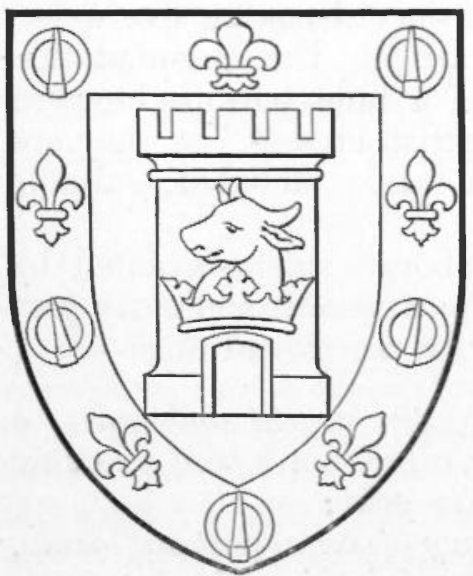

ARMS OF THE TOWX OF GRATESEND.

gent, on an embattled tower gules, a bull's head sable, horned and maned or, issuing from a gold coronet, all within a bordure azure charged with five fleurs-de-lis and as many bickles or.

It is curious that eight out of these ten shields are characterised by a bordure or a chief, or charges in chief, features that are not found in any of the ancient arms which have been described.

Among the shields of this period that are distinguished by having a chief is an interesting group of comparatively 
simple design, which from their general likeness would seem to have been suggested by or to have had a common origin.

They are:

Canterbury: Argent, three Cornish choughs proper; on a chief gules, a lion of England. Engraved on the city seal in 1541-2, in place of the martyrdom of St. Thomas;

Maidstone : Or, a fess wavy azure between three torteaux; on a chief gules, a lion of England. Engraved on the first

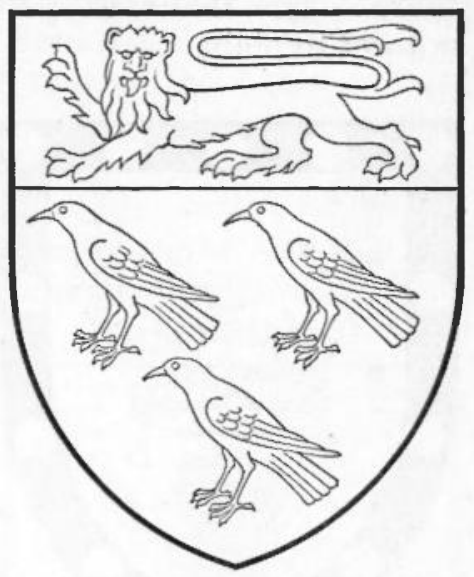
common seal of arms of the oity of canterbury. 1548 ;

Rochester: Argent, on a cross gules the letter $\mathfrak{l}$ or: on a chief gules, a lion of England. On the mayoralty seal of 1619 ;

Chichester: Argent, guttée sable; on a chief indented gules, a lion of England. Granted 1570.

Sudbury: Sable, a hound sejant argent; on a chief gules, a lion of England between two fleurs-de-lis or. Granted 1576.

Jyme Regis: Argent, two bars wavy argent; on a chief gules, a lion of England. Probably granted circa 1591.

Two of these, Chichester and Sudbury, were granted by Robert Cooke, when Clarencieux King-of-Arms, and it is curious that the Rochester arms are almost identical with the official arms of Clarencieux. But Cooke can hardly have been responsible for all six shields, since he was not admitted a member of the Heralds' College until 1561.

As to the significance of these shields, apart from the royal chief, the Cornish choughs of Canterbury are the arms ascribed to St. Thomas; the blue wavy fess of 
Maidstone alludes to the river Medway, and the torteaux to Archbishop Courtenay, the founder of the college; the wavy bars of Lyme refer to its site by the sea; and the Sudbury hound is from the arms of the unfortunate Archbishop Simon de Sudbury, who was born there. The black drops on the Chichester shield I cannot yet explain.

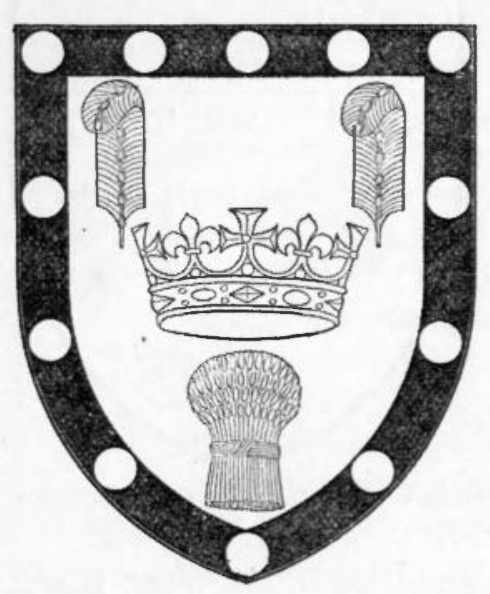

Some of the elaborate shields before referred to aim, in a more or less clumsy way, at being full of meaning. The arms of Morpeth for instance are asserted in Hervy's wrant to be "the olde and Auncient armes of the sayde Sir Roger Marlaye theron a castell golde for the augmentacon." Those of Newark again are a modified combination of the arms and crest of Manners, dukes of Rutland, who were connected with arms of the вовогgh of rtshram. the place; and the arms of Cambridge still punningly allude to the name of the town. The arms of Evesham were designed by Camden with special reference to Henry, prince of Wales, duke of

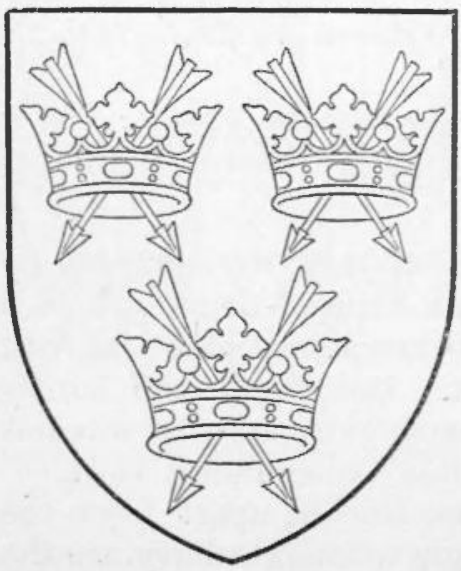
Cornwall, and earl of Chester, and ingeniously refer to all three dignities, though not without infringing one of the cardinal laws of armory, that colour must not be laid upon colour. The coronet is that which belonged to prince Henry as the son of the king; the feathers refer to his dignity as prince of Wales, and the garb to his earldom of Chester, while the bordure alludes ARYS OF THE TOWN OF BURY ST. EDYTNDS. to his dukedom of Cornwall. 
The arms of Bury St. Edmunds, from their good character, may be earlier than 1606 , when they were included in the grant of a crest to the town. This crest is a wolf sejant holding between his paws the crowned head of St. Edmund, and the arms represent the weapons with which the king was martyred, combined with the three crowns of East Anglia.

The Hadleigh arms, but for the use of erminois, are also of sufficiently simple character to be earlier than 1618, when they were granted by Camden, together with a crest; on a mount vert, a lamb proper, holding a banner azure charged with a woolsack argent, the staff or. Both arms and crest allude to the woollen cloth trade of the town.

In addition to arms that were formally granted by the Heralds' College, there are, as I have already said, many that have been formed during the same period, by placing upon shields the devices of common and official seals. There are also others to be found on seals and other contemporary authorities, that resemble in character the productions of the Heralds' College, but no certain evidence of their origin is arms or the town of rading. forthcoming.

It is, however, curious that in a good many cases the appearance of these particular arms is coincident with the dates of various heralds' visitations at which they were duly admitted and allowed, and I think there can be little doubt that most, if not all of them, were invented by the heralds themselves to gratify the vanity of the corporations, and perhaps in consideration of a larger fee than that charged for a formal grant of arms.

Of arms formed of devices of seals, we have those of Barnstaple and Torrington (1564), Bridport (1565), Windsor and Reading (1566), Pontefract (1584-5), Totnes (1620), and Weymouth (1623); all allowed at the 
several heralds' visitations of which the dates are given. Those of Calne appear on the seal of 1566 .

Other examples, the approximate dates of which it is not so easy to fix, since

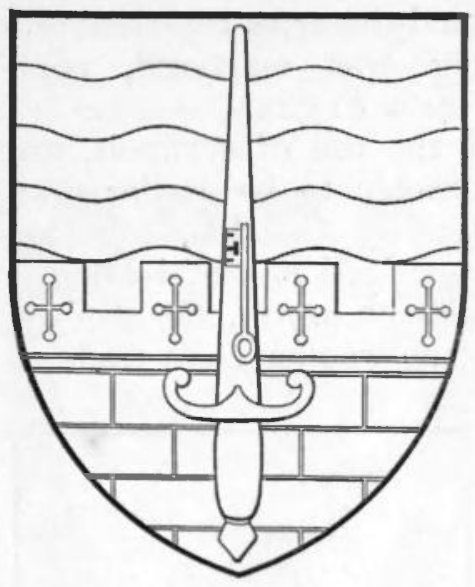

ARYS OF THE CITY OF BATH. they are not entered in visitations, nor shown on dateable seals, are afforded by the arms of Harwich, Portsmouth, Carlisle, Winchester, Northampton, Bath, Andover, Leicester, Tamworth, Wells and Wallingford.

One or two apparently unlikely cases of arms derived from seals may be selected by way of illustration.

The arms of Carlisle, as shown on the mayoralty seal of 1640 , and the statute merchant seal of 1670 , are blazoned as or, on a crosspattee between four roses gules, a fifth rose of the field. These are clearly derived

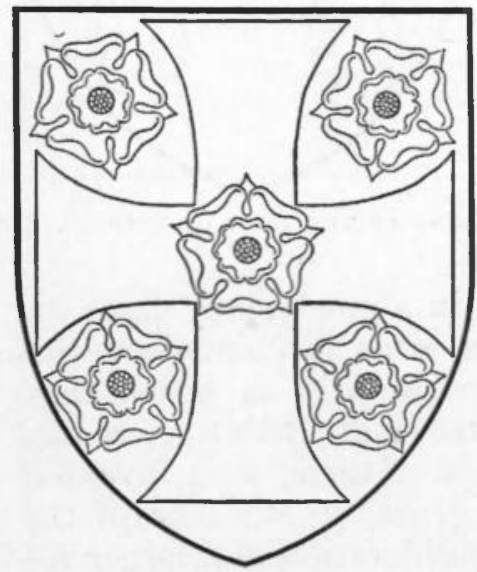

ARMS OP THE CITY OF CARLISLE. from the early counterseal or reverse of the city seal, which displays an attenuated cross-pattée between four sexfoils, and charged with another sexfoil.

The arms of Abingdon, which are given in the Visitation of 1566 as vert, a cross patonce between four crosses-pattees or, probably had a similar origin.

In the Visitation of Devon in 1564 , the arms of Torrington are somewhat incorrectly given as argent, two bars uavy. over all a fleur-de-lis, and within a bordure engrailed, all sable. These are borrowed from the fine fifteenth century seal, the device of which is a fleur-de-lis between two letters $t$, on the waters of the 
river Torridge. From the cusped circle that encloses this has been evolved the bordure engrailed.

It is obvious that the shields thus derived must vary considerably in interest and excellence. To such as that of Portsmouth, azure, a star within the horns of a crescent $o r$, or of Leicester, gules, a cinquefoil ermine, the badge of the ancient earls of Leicester, no possible objection can be made, but compositions like the arms of Bath, or Bridport, or Windsor can only be compared with some of the productions that have emanated from the Heralds' College.

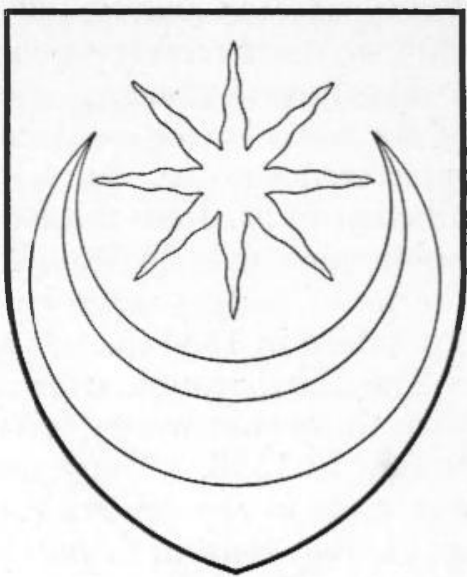

ARMS OF THE BOROCGH OF PORTSMOUTH.

Amongst arms for which no formal grant exists that seem from their character to have been concocted by the heralds at their visitations, at which they were allowed, are those of Poole and Marlborough (1565), Woodstock (1574), and Beverley (1584-5). To which may be added those of Grantham (seal of 1581), and of Westbury (seal of 1597).

Three of these have chiefs or charges in chief, and three have bordures.

The Poole arms are variously blazoned, but they are almost certainly derived from those of James Blount, lord Mountjoy, who was lord of the manor 15441581, barry nebulee or and sable, with added charges allusive of the town's maritime position. They should

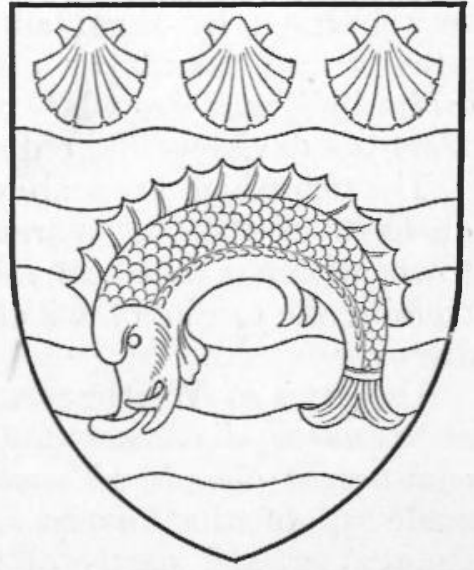

ARMS OF THE BOROUGH OF POOLE. probably therefore be blazoned: Barry wavy sable and or, a dolphin argent and in chief three escallops gold. 
The arms of Woodstock, partly allude to the placename and partly to the neighbouring forest, and are gules, the stock of a tree erased or, and in chief three stags' heads caboshed argent; all within a bordure silver charged with eight oak trees (or leaves).

The Beverley arms, argent, three bars azure, on a chief of the last a beaver couchant regardant or, are often borne quartered with or, an eagle displayed azure, perhaps in allusion to St. John the Evangelist, in whose honour the noble minster is dedicated. The arms are thus shown on the waits' badges made in 1573 , and in the Visitation of Yorkshire in 1584-5.

The Marlborough arms are worthy of being compared with those that were devised for the city of Gloucester by Barker in 1538. They are: per saltire gules and azure, two cocks in fess between a bull statant in chief and three greyhounds courant in pale in base, all argent; on a chief or, between two roses gules, a pale azure thereon a castle silver. Tiuese extraordinary arms were probably concocted by Hervy, Clarencieux, at his Visitation in 1565 , when he "ratified and confirmed" them in perpetual memory of "the duty and homage heretofore said and done (time out of mind) by the burgesses and community to the mayor for the time being, his aldermen and brethren of the said town, at the receiving of the oath by any burgess by them admitted; at which time they do present unto the mayor a leash of white greyhounds, one white bull, and two white capons." " The castle is taken from the device of the old seal.

The Grantham arms are composed of the gold and blue checkers of the De Warennes, the ancient lords of the town, within a bordure sable charged with eight silver trefoils, the origin of which I have not yet been able to discover.

The arms of Westoury are: quarterly or and azure, a cross quartered patonce and fleury, and a bordure charged uith twenty lioncels, all counterchanged. These are partly made up of the Pavely arms, azure, a cross fleury (or patonce) or, and partly of those of Longespee, azure, six

1 William Berry, Encyclopœdia Heraldica (London), i. s.r. Cities, Boroughs, Towns Corporate, \&c. 
lioncels or, but the quartered cross, which seems to have hitherto escaped notice, has yet to be fully explained. It is plainly shown on the town seal, which was given in 1597 , and may represent a combination of two differenced shields of Pavely.

Besides the arms already described there are many, neither derived from seals nor recorded to have been granted, of which it is difficult to learn the origin and in some cases to fix a date.

A few from their good and simple character perhaps had an early origin, even previous to the establishment of the Heralds' College. Amongst these are the arms of

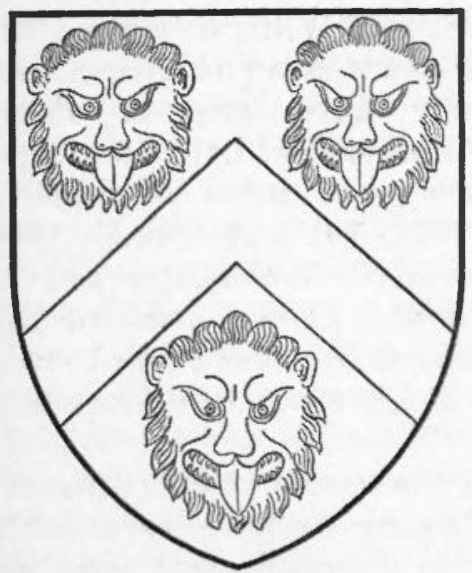

$\triangle R Y S$ OF THE BOROUGH OF . STRATFORD-ON-ATON.

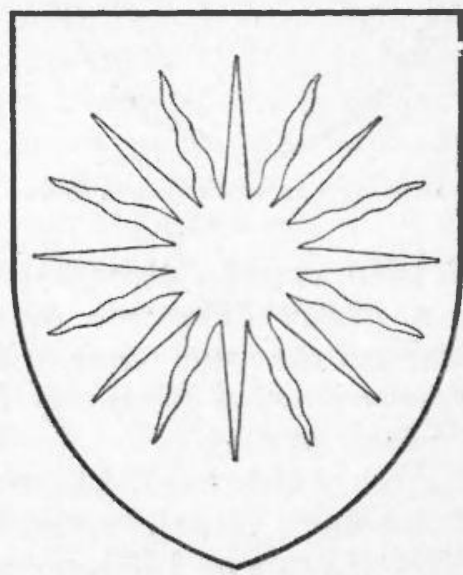

AIMS OF THE BOROCGH OF BANBURY.

Newcastle, gules, three castles two and one argent; Boston, sable, three crowns in pale or (on the seal of 1545); Stratford-on-Avon, or a chevron azure between three lion's faces gules (on the seal of 1553); Southwold, sable, two arrous in saltire enfiled with a coronet, with the letter $S$ in base, all or (before 1561): and Bedford, per pale argent and gules, a bend azure (Visitation of 1566). To which may be added as examples of simple arms the golden saltire of St. Albans (seal of 1554), the blazing sun of Banbury (seal of 1584 ?), and the Durham cross (seal of 1606), the golden fleece of Leeds (seal of 1626) and the bars of Salisbury (Visitation of 1623), and the punning 
arms of St. Ives, argent, an ivy branch vert, given on the seal of 1690 .

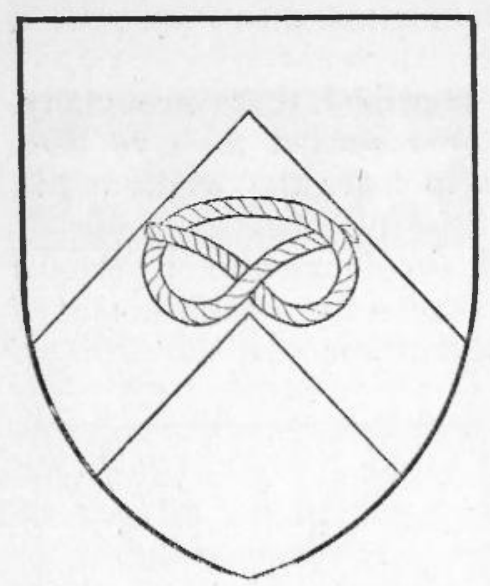

ARMS OF THE TOWN OF STAFFORD.

The meaning or origin of these arms, is not always apparent. Those of Southwold plainly refer to St. Edmund, and the golden Heece of Leeds to the staple trade of the place, while the town of St. Albans has appropriated the arms of the suppressed abbey. The arms of Stratford closely resemble those of William Hervy, Clarencieux King of Arms, who may have granted them. Another shield, that found on the great mace of Stafford (1613-14) and Speed's map of 1610 , or, on a chevron gules a Stafford knot argent (?) is a pretty difference of the well-known arms of the family of the same name. Those of Newport (Mon.), or, a chevron reversed gules, may be another way of diflerencing the same arms.

From 1635 to 1842 . with the possible exception of Richmond (Yorks), which is stated to have received a grant of arms in 1665, no armorial ensigns seem to have been granted to any city or town, save Liverpool. Although this important place had had its first charter so long ago as 1207 , it remained without arms until 1797 , when there were granted to it, argent, a cormorant holding in his beak a branch of seaueed proper, with crest and supporters to match.

There is, however, no reason to assume that during these two centuries no other towns adopted arms. On the contrary, the formation of arms by placing upon shields the devices of seals continually went on, as at Guildford and Northampton, and a few towns, as is shown by their snields and maces, etc. adopted arms of good character. Two of these deserve special mention. On the seal made in 1626 for the town of Leeds when it was first incorporated is a shield bearing the golden fleece, supported 
by two crowned owls. The fleece of course alludes to the wool trade of Leeds, and the owls were adopted in honour of Sir John Saville, knight, the first alderman, who bore owls as his arms and crest.

In 1662 , on the granting of the second cliarter, a new seal was made, with the addition to the arms of $a$ chief sable charged with three silver mullets. These were added to commemorate the first mayor, 'Thomas Danby, who bore a similar chief in his own arms. Despite the breach of heraldic law in placing colour upon colour, it must be allowed that the townsfolk devised for themselves a pretty and most appro-

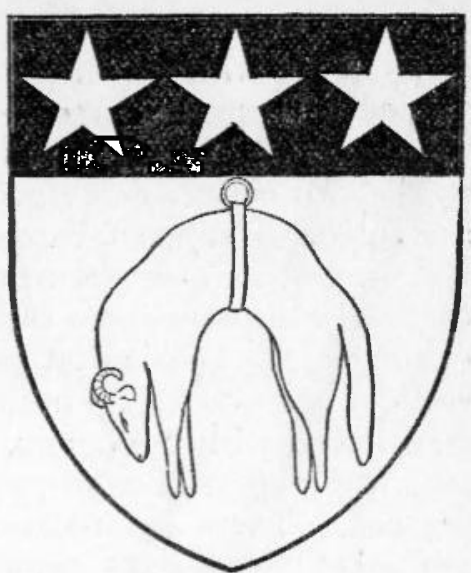

ARMS OF THE CITY OF LEEDS. priate shield of arms.

During the seventeenth and eighteenth centuries the city of Chester used a second shield of arms, of better design than, if not of so much historic interest as its thirteenth century arms. It is simply the arms of the ancient earldom of Chester, azure three garbs or, surmounted by the sword of state in pale proper.

Of the arms assumed by or granted to the numerous towns that have sprung up or been incorporated since 1836 it is unnecessary to speak. I will only say that nearly one hundred arms and crests have during these sixty years been added to our list, and that they are generally thoroughly unworthy of the nineteenth century.

I have so far only treated of the arms borne by our municipalities, but there are a few words to be said on the question of crests and supporters. Theoretically the use of a crest by a corporation is an absurdity, since a crest is essentially the ornament that surmounts a helm, and a corporation not being an individual cannot wear a helm, nor properly treat it even as a device. A similar objection may be taken to the use of shields, but from very earjy times these were used as ornaments and for 
decorative purposes, and while heraldry was a living science were allowed to be borne by towns. It being conceded that shields might be assumed by corporations, the use of supporters, would naturally follow, yet as a matter of fact, no city or town, previously to 1500 . appears to have used either a crest or supporters proper. A few cases occur where a shield or badge on a seal is accompanied by true supporters, as on the Colchester seal, where the shield is held by two lions, and on the Congleton seal, where two conger eels stand on their tails in the manner and place of supporters, on either side of a lion and tun. But in neither case nor in any other has the use of these creatures as permanent supporters continued. In a few examples, the beasts that are so often introduced at the sides of seals to fill up otherwise vacant spaces have been transferred with the device into a shield, as at Northampton, where two lions supporting a castle have been so derived. There is, however, no example of the use of permanent supporters before 1561 .

The earliest instance of a crest by a municipality is furnished by the counterseal of the city of London, which was made in 1539 in place of an older one then broken because it bore an image of St. Thomas of Canterbury. The new seal, which is that now in use, bears the city arms surmounted by a helm, mantling and crest, a dragon s wing expanded argent, charged with a cross gules, in allusion to the monster slain by St. George.

There seem to be no other examples earlier than the reign of Elizabeth, when grants of crests and, for the first time, of supporters were made to Ipswich and Newark (1561), Exeter (1564), Bristol (1569 ?), Cambridge, Southampton and Newcastle (1575), Chester (1580), and a few other places. Crests only were granted to Boston (1568), Launceston (1573), Sudbury (1576), and Eye (1592), and probably to Southwold (1561).

A few cases also occur in the seventeenth century, e.g., Bury St. Edmunds (arms and crest, 1606), Hadleigh (arms and crest, 1618), Hereford (arms, crest and supporters, 1645 ), and perhaps of crest and supporters to the city of Oxford.

But by far the greater number of our old cities and towns, including York, Lincoln, Norwich, Carlisle, Lynn, 
Shrewsbury, Plymouth, and Gloucester, have never used either crests or supporters.

There are many other interesting points in connection with municipal heraldry which might properly have been included in this paper, but its already undue length compels me to omit them on this occasion. The subject is by no means exhausted, and the various arms I have referred to only form part of what are known and have been selected as good and typical examples.

It is possible that many of the derivations of the arms which I have suggested may be open to question, but if the new light now thrown upon the origin of municipal heraldry will tempt someone else to pursue the subject further, my own humble endeavours in that direction will not have been in vain. 